\title{
Determining Distribution and Size of Larval Pacific Geoduck Clams (Panopea Generosa Gould 1850) in Quartermaster Harbor (Washington, USA) Using a Novel Sampling Approach
}

Bonnie Becker

University of Washington Tacoma, bjbecker@uw.edu

Michael D. Behrens

Pacific Lutheran University

Yvonne A. Shevalier

University of Washington Tacoma

Christine M. Henzler

University of California - Santa Barbara

Elizabeth A. Hoaglund

University of California - Santa Barbara

See next page for additional authors

Follow this and additional works at: https://digitalcommons.tacoma.uw.edu/ias_pub

Part of the Marine Biology Commons

\section{Recommended Citation}

Becker, Bonnie; Behrens, Michael D.; Shevalier, Yvonne A.; Henzler, Christine M.; Hoaglund, Elizabeth A.; and LeMay, Brenda K., "Determining Distribution and Size of Larval Pacific Geoduck Clams (Panopea Generosa Gould 1850) in Quartermaster Harbor (Washington, USA) Using a Novel Sampling Approach" (2012). SIAS Faculty Publications. 11.

https://digitalcommons.tacoma.uw.edu/ias_pub/11 
Authors

Bonnie Becker, Michael D. Behrens, Yvonne A. Shevalier, Christine M. Henzler, Elizabeth A. Hoaglund, and Brenda K. LeMay 


\title{
DETERMINING DISTRIBUTION AND SIZE OF LARVAL PACIFIC GEODUCK CLAMS (PANOPEA GENEROSA GOULD 1850) IN QUARTERMASTER HARBOR (WASHINGTON, USA) USING A NOVEL SAMPLING APPROACH
}

\author{
BONNIE J. BECKER, ${ }^{1 *}$ MICHAEL D. BEHRENS, ${ }^{1,2}$ YVONNE R. A. SHEVALIER, ${ }^{1}$ \\ CHRISTINE M. HENZLER, ${ }^{3}$ ELIZABETH A. HOAGLUND ${ }^{3}$ AND BRENDA K. LEMAY ${ }^{1}$ \\ ${ }^{1}$ Environmental Science, Interdisciplinary Arts and Sciences, University of Washington Tacoma, 1900 \\ Commerce Street, Box 358436, Tacoma, WA 98402; ${ }^{2}$ Department of Biology, Rieke Science Center, \\ Pacific Lutheran University, Tacoma, WA 98447; ${ }^{3}$ Marine Science Institute, Building 520, University of \\ California at Santa Barbara, Santa Barbara, CA 93106
}

\begin{abstract}
Realistic species-specific information about larval life history is necessary for effective management of shellfish and parameterization of larval connectivity models. The patchiness of dispersing larvae, and the resources needed for sorting and identifying them, has limited many studies of larval distribution in the field, especially for species that are less common. In particular, little is known about in situ larval distribution of Pacific geoduck clams (Panopea generosa Gould 1850), a commercially important species found in Puget Sound, WA. A novel approach - time-integrating larval tube traps paired with molecular identification and sorting (FISH-CS) - was used to determine the distribution of geoduck larvae over 4 mo at 3 stations in Quartermaster Harbor. Larvae were found consistently at the surface and thermocline rather than at the bottom. More and larger larvae were captured in the inside and middle of the harbor than the outer harbor, indicating at least some larval retention. Two pulses of larvae were captured, in March and late May to early June. Size-frequency distributions of larvae indicate that these were 2 separate cohorts of larvae, with the possibility of a pulse of larvae from elsewhere toward the end of the season. The only physical parameter associated with relative larval abundance was degree of stratification, although the association was weak. These data represent the first reported study of geoduck larval distribution in the field and the first use of the FISH-CS technique for field collections. In the future, this approach can be used to answer many relevant management questions locally and more broadly, including quantifying larval export from shellfish farms, placement of restoration sites and marine protected areas, and spread of invasive species.
\end{abstract}

KEY WORDS: Pacific geoduck, clam, Panopea generosa, larval ecology, fluorescent in situ hybridization, Puget Sound

\section{INTRODUCTION}

To manage shellfish populations effectively, it is important to understand and quantify their larval dispersal and connectivity (Fairweather 1991, Orensanz et al. 2006). Management actions such as design of marine reserve networks, control of invasive species, and placement of closure and restoration sites all depend on the ability to map and predict the movement of individuals throughout an area (reviewed in Levin (2006) and Cowen \& Sponaugle (2009)). Because bivalve adults are relatively sedentary, the exchange among geographically separated subpopulations occurs prerecruitment, most notably during the planktonic larval stage. Most bivalves have planktotrophic veliger larvae with low swimming ability, and it was historically assumed that their larvae travel great distances during their planktonic larval duration (Bayne 1976, Widdows 1991). Like many invertebrate larvae, their transport was often predicted by using models of water transport and simulating larvae using passive particles at a fixed depth (Sponaugle et al. 2002, Levin 2006, Fiksen et al. 2007). On the other hand, a number of empirical studies have found different patterns of connectivity between co-occurring species that were assumed to have similar larval life histories (Hamm \& Burton 2000, Parker et al. 2003, Becker et al. 2007, Carson et al. 2010), indicating that average currents do not predict larval dispersal accurately without accounting for behavior and other species-specific larval characteristics. In addition, it has long been understood that estuarine larvae of various taxa can migrate vertically to take

*Corresponding author. E-mail: bjbecker@uw.edu DOI: $10.2983 / 035.031 .0315$ advantage of oscillating tidal currents or directional currents that differ with depth to enhance retention or increase export (Prytherch 1929, Carriker 1951, Bousfield 1955, Cronin \& Forward 1979). Even in more complex coastal systems, recent work has demonstrated that weak-swimming bivalve larvae can regulate vertical position to take advantage of depth-dependent advection (Shanks \& Brink 2005, Ma et al. 2006) or be retained within less than ten of kilometers from their natal origins (McQuaid \& Phillips 2000, Becker et al. 2007). It is clear that to be able to accurately predict and explain larval connectivity patterns, species-specific vertical distribution and behavior, especially those determined empirically in the field (discussed by Young (1995)), must be determined for incorporation into oceanographic models (Kingsford et al. 2002, Sponaugle et al. 2002, Fiksen et al. 2007, North et al. 2008, Cowen \& Sponaugle 2009, Willis 2011).

The Pacific geoduck clam (Panopea generosa Gould 1850, formerly Panopea abrupta, see Vadopalas et al. (2010)) is a large, long-lived hiatellid clam that is both commercially important and highly managed in the Puget Sound region of western Washington. Because this species is raised commercially, much is known about its ex situ larval biology. Like most bivalves, geoduck are dioecious broadcast spawners that can release tens of millions of eggs per year (Goodwin \& Pease 1989). They usually spawn multiple times per season, with 1-2 million eggs per spawn, but can release as many as 20 million eggs per spawning event (Goodwin \& Pease 1989). Spawning may occur as early as January, although it is believed that natural spawning occurs between March and July (Goodwin 1976), possibly earlier in south Puget Sound (Goodwin \& Pease 1989). 
The planktonic larval duration of geoduck, like most invertebrate larvae, is dependent on temperature and environmental conditions. The shortest reported laboratory-determined time was 16 days (at $16^{\circ} \mathrm{C}$ ) and the longest was 47 days (at $14^{\circ} \mathrm{C}$ ), although the latter is probably an overestimate as a result of contamination problems (Goodwin \& Pease 1989). In hatcheries, with highly optimized growing conditions, pediveligers are competent to undergo metamorphosis after approximately 24 days at $14-15^{\circ} \mathrm{C}$ (E. Jones, Taylor Shellfish, pers. comm., March 20, 2012). During this time, they grow from approximately $100-\mu \mathrm{m}$ veligers to $350-400-\mu \mathrm{m}$ pediveligers (Goodwin et al. 1979). After settlement, the clams remain at or near the surface of the substrate for some time while their siphons develop (Goodwin \& Pease 1989). When they reach a size of 1.5-2 mm, they begin to dig into the sediment; when they reach $5 \mathrm{~mm}$, they tend not to change locations for the rest of their lives (Goodwin \& Pease 1989).

Despite the large quantity of information about geoduck larval biology in the laboratory, relatively little is known about the distribution, behavior, or in situ dispersal of the pelagic larvae (Straus et al. 2008). A population genetic study by Vadopalas et al. (2004) indicated that there is little genetic differentiation and no evidence of "isolation by distance" among geoduck populations in Puget Sound. One notable exception to the observed panmixia was the differentiation of a single site, Freshwater Bay, in the Strait of Juan de Fuca. More genetic differentiation was observed at larger spatial scales (500$1,000 \mathrm{~km}$ ) by Miller et al. (2006), who found differentiation among populations in British Columbia and a pattern of isolation by distance. Population genetic studies can be very useful for determining the average amount of genetic exchange among populations over multiple generations. As a result of the low numbers of individuals needed to homogenize genetic signatures, however, direct approaches are necessary to determine the amount of exchange among populations at the smaller timescales relevant to management and to characterize transport mechanisms (Cowen \& Sponaugle 2009).

We had 3 goals for this work: (1) to determine the temporal and spatial distribution of geoduck larvae throughout most of their reproductive season in a small harbor in south central Puget Sound, (2) to compare this distribution with water conditions to determine whether any physical parameters are associated with geoduck relative larval abundance, and (3) to use individual larval size measurements to describe the demographics of natural geoduck larval populations and to determine if there are ontogenetic changes in larval spatial distribution.

In the past, sampling of larvae in the field has been limited by 3 technical challenges. First, all but the most abundant larvae are patchy in both time and space, requiring a large number of samples to capture them using plankton nets and pumps (Gaines \& Bertness 1993). Second, the process of sorting rare larvae from samples full of other organisms and particles can be time-consuming and inaccurate. Last, when larvae are isolated, it can be slow and difficult, or impossible, to identify them to species using morphological features, especially in bivalve larvae that tend to look quite similar. Although there are numerous studies that have used the direct sampling and visual sorting approach successfully, sampling resolution is limited by the resources available. In this study, 2 novel methods - passive larval trapping and fluorescence in situ hybridization followed by cell sorting (FISH-CS) - were paired to overcome these challenges and improve the speed and accuracy of sampling bivalve larvae.

\section{METHODS}

\section{Probe Development and Testing}

Larvae of $P$. generosa were identified and counted by FISH-CS according to the methods of Henzler et al. (2010). Plankton samples were hybridized with a fluorescently labeled, speciesspecific DNA probe (5' TET-labeled, sequence 5'-CAGAGA GCAGACGCGAAT-3') targeting the $18 \mathrm{~S}$ small ribosomal subunit RNA and then sorted based on fluorescence by a largeparticle cell sorter. Sorted particles were examined to enumerate the bivalve larvae, and larvae were reserved for later measurement and verification of identification as P. generosa.

The probe was designed using the program ARB (v. 07.12.07org; Ludwig et al. (2004)) searching for an 18-nucleotide probe targeting $P$. generosa in a database of high-quality mollusc $18 \mathrm{~S}$ sequences (full-length $18 \mathrm{~S}$ sequences with sequence, alignment, and pintail qualities greater than $75 \%$ ) downloaded from Silva's comprehensive ribosomal RNA database (Pruesse et al. 2007).

The specificity of the probe was tested using dot blot hybridization following the methods of Le Goff-Vitry et al. (2007) and as adapted by Henzler et al. (2010) (Fig. 1). DNA was extracted from 96 individual bivalves representing 17 species: 12 P. generosa, 8 Panopea globosa, 10 Hiatella arctica, 2 Venerupis philippinarum, 5 Tellina sp., 5 Zirphaea pilsbryi, 4 Mytilus galloprovincialis, 4 Mytilus trossulus, 4 Mytilus californianus, 6 Crassostrea gigas, 6 Crassostrea sikamea, 8 Clinocardium nuttallii, 4 Adula diegensis, 6 Macoma sp., and 6 Musculista senhousia. All but $P$. globosa and A. diegensis are found in Puget Sound and surrounding waters (Coan et al. 2000, Ruiz et al. 2000, Rocha-Olivares et al. 2010). An approximately 385-bp fragment of the $18 \mathrm{~S}$ gene containing the probe region was PCR amplified using primers from Turbeville et al. (1994) (forward: 5' -CA GGTCTGTGATGCYC-3'; reverse: 5' -TGATCCATCTGC AGGTTC-3'). The PCR products were purified using a Bioneer (Alameda, CA) PCR purification kit, and then quantified using a Nanodrop ND-1000 spectrophotometer (Thermoscientific). Approximately $750 \mathrm{ng}$ of the fragment of 18S DNA from each bivalve was applied to an $\mathrm{N}+$ Hybond membrane (GE Live Sciences) using a Bio-Dot Microfiltration apparatus (Biorad), and bound to the membrane by UV crosslinking at $70,000 \mathrm{~kJ} / \mathrm{cm}^{2}$. The probe was prepared and hybridized to the dot blot using the Alk Phos Direct Labeling kit with CDP-Star Detection reagent (GE Life Sciences), following the modified protocol for short oligonucleotide probes. Briefly, an unlabeled oligonucleotide matching the $P$. generosa probe sequence was crosslinked to alkaline phosphatase (by incubating at $37^{\circ} \mathrm{C}$ for $5 \mathrm{~h}$ ). The blotted membrane was prehybridized in $28 \mathrm{~mL}$ hybridization buffer at $37^{\circ} \mathrm{C}$ for $15 \mathrm{~min}$ before the labeled probe was added to the buffer at a concentration of $14 \mathrm{ng} / \mathrm{mL}$ to hybridize overnight. Blots were then washed following protocol directions, and CDP-Star detection reagent was added at a concentration of $40 \mu \mathrm{L} / \mathrm{cm}^{2}$ to detect probe binding. For visualization, HyBlot CL Film (Denville Scientific) was exposed to the blot for $30 \mathrm{~min}$, and then developed. In addition to P. generosa, the probe also hybridized to several individuals of the congener $P$. globosa 
A

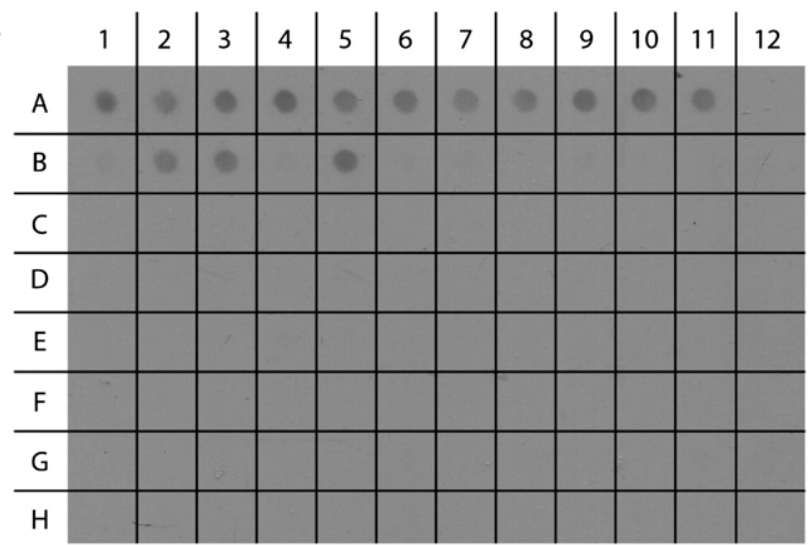

B

\begin{tabular}{c|c|c|c|c|c|c|c|c|c|c|c|c} 
& 1 & 2 & 3 & 4 & 5 & 6 & 7 & 8 & 9 & 10 & 11 & 12 \\
\hline A & Pabr & Pabr & Pabr & Pabr & Pabr & Pabr & Pabr & Pabr & Pabr & Pabr & Pabr & \\
\hline B & Pglo & Pglo & Pglo & Pglo & Pglo & Pglo & Pglo & Pglo & Msac & Msac & Msac & Msac \\
\hline C & Harc & Harc & Harc & Harc & Harc & Harc & Harc & Harc & Harc & Harc & Vphil & Vphil \\
\hline D & Tell & Tell & Tell & Tell & Tell & Zirph & Zirph & Zirph & Zirph & Zirph & Prot & Prot \\
\hline E & Mgal & Mgal & Mgal & Mgal & Mtro & Mtro & Mtro & Mtro & Mcal & Mcal & Mcal & Mcal \\
\hline F & Cgig & Cgig & Cgig & Cgig & Cgig & Cgig & Csik & Csik & Csik & Csik & Csik & Csik \\
\hline G & Clino & Clino & Clino & Clino & Clino & Clino & Clino & Clino & Adie & Adie & Adie & Adie \\
\hline H & Mac & Mac & Mac & Mac & Mac & Mac & Msen & Msen & Msen & Msen & Msen & Msen
\end{tabular}

Figure 1. Dot blot to assess genetic probe accuracy when tested among various species. (A) Dot blot with geoduck probe. (B) Dot blot layout. Adie, Adula diegensis; Cgig, Crassostrea gigas; Clino, Clinocardium nuttallii; Csik, Crassostrea sikamea; Harc, Hiatella arctica; Mac, Macoma balthica; Mcal, Mytilus californianus; Mgal, Mytilus galloprovincialis; Msac, Modiolus sacculifer; Msen, Musculista senhousia; Mtro, Mytilus trossulus; Pabr, Panopea generosa; Pglo, Panopea globosa; Prot, Protothaca; Tell, Tellina; Vphil, Venerupis philippinarum; Zirph, Zirphaea.

(endemic to the Gulf of California, Mexico (Rocha-Olivares et al. 2010)) (Fig. 1).

\section{Larval Trap Design}

Larval tube traps, similar to those described by Yund et al. (1991) and used in various habitats (e.g., Yund et al. 1991, Gaines \& Bertness 1993, Todd 2003, Metaxas 2004, Arellano \& Young 2010), were constructed from a clear shipping tube $(30.5 \mathrm{~cm}$ long with a radius of $3.8 \mathrm{~cm}$, aspect ratio, 8:1) with a dense fixative in the bottom that captures larvae passively (Fig. 2). This aspect ratio is somewhat lower than that used by Yund et al. (1991) (12:1), although higher than those used in the deep sea (such as 7.4:1 used by Metaxas (2004) and 6:1 used by Arellano and Young (2010)), a particularly calm environment. The main concern with maintaining a high aspect ratio is avoiding resuspension of the sample. In this study, we were expecting relatively weak currents (predicted tidal currents less than 0.6 knots, Tides and Currents [Nautical Software 1996]) and limited wave action at our protected site, and our preliminary field studies indicated that little mixing had occurred in our traps. The tubes were sealed on one end, filled with filtered

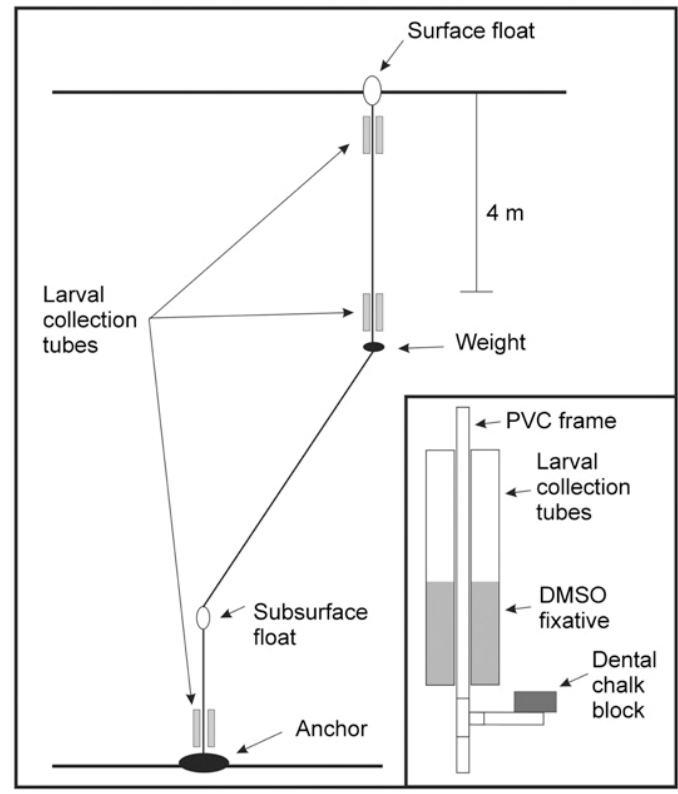

Figure 2. Diagram of buoy and passive larval trap design. Tube traps were designed to capture geoduck larvae in salted dimethylsulfoxide at the bottom of a clear plastic mailing tube. An array with 2 traps and a calcium sulfate "puck" for measuring relative water flow were attached by divers to a buoy at 3 depths.

seawater with a salinity of 27 , and $40-80 \mathrm{~mL}$ fixative was inserted in the bottom using a long pipette. Because the most common preservative used in this type of trap, formalin, would degrade the larval DNA, a salted dimethylsulfoxide (DMSO) fixative was used (5 M NaCl in deionized water, 10\% DMSO, food coloring or bromophenol blue as needed) as described by Comtet et al. (2000). The density of the salted DMSO effectively kept the fixative at the bottom of the tubes, and the dye was used as an indicator that the fixative remained in place for the entire sampling period. Two traps were attached to a $60-\mathrm{cm}$ PVC frame with cable ties for deployment (Fig. 2). The contents of 1 trap were used for analysis and the other was archived.

As with any collector that integrates over time using an Eulerian approach, these traps capture the flux of larvae past the mouth of the traps, including a component of relative abundance and water flow (Yund et al. 1991, Gaines \& Bertness 1993). Many studies have taken advantage of this quality by using similar traps to measure "larval supply," defined operationally as the number of larvae passing by settlement sites (Gaines \& Bertness (1993), Castilla \& Varas (1998), Dudas et al. (2009), Arellano \& Young (2010), and as reviewed by Pineda et al. (2010)). For this study, we were interested in drawing comparisons in relative abundance, and therefore must control for differences in water flow.

To monitor relative water flux at each trap, a calcium sulfate "puck" (following Gaines \& Bertness (1993)) was attached to each frame. Pucks were made of dental chalk (Die Keen Blue/ Burman Industries) poured into a 7.6-cm-diameter and $2.5-\mathrm{cm}-$ deep circular mold with an embedded $7.6-\mathrm{cm}$ stainless steel screw. They were painted with 2 coats of polyurethane (Helmsman Spar Urethane, clear gloss/Minwax) on the sides and bottom (the screw side of the puck), leaving the flat top surface unpainted. Prepared pucks were placed in a $60^{\circ} \mathrm{C}$ drying oven for at least $24 \mathrm{~h}$ to remove 
all moisture, and pucks were weighed before deployment. On the bottom of each PVC frame, a T joint was used to attach the pucks with the dissolution surface facing up to measure water flux across the surface, similar to the tops of the tubes (Fig. 2). After retrieval from the field, pucks were dried and weighed again to determine change in mass. The unpainted calcium sulfate was assumed to dissolve at a rate proportional to flux of water past the trap, and was used as a proxy for water flow. Relative water flow (as measured by chalk dissolution in grams) was used as a covariate in our analyses to account for differences in flow.

\section{Field Sampling}

Larval tube traps were deployed on buoys in Quartermaster Harbor $(\mathrm{QMH})$, a small $\left(12.3 \mathrm{~km}^{2}\right)$ (University of Washington 1976), shallow embayment in central Puget Sound between Vashon and Maury Islands $\left(47^{\circ} 22^{\prime} \mathrm{N}, 122^{\circ} 28^{\prime} \mathrm{W}\right.$; Fig. 3). QMH is longer $(8 \mathrm{~km})$ than wide $(2.5 \mathrm{~km}$ maximum) and is oriented roughly north-south, with a bend that separates the shallow (6-10 m), muddy inner harbor from the deeper, sandier outer harbor $(12-18 \mathrm{~m})$. There is a sill (approximately $11 \mathrm{~m}$ ) near the outlet at the southern end of QMH, beyond which there is a sharp drop-off to a depth than $200 \mathrm{~m}$ in Dalco Passage and the main basin of Puget Sound. To the north in the inner harbor, flow is blocked between the islands by a shallow bar that was closed artificially to construct a road in 1916 (University of

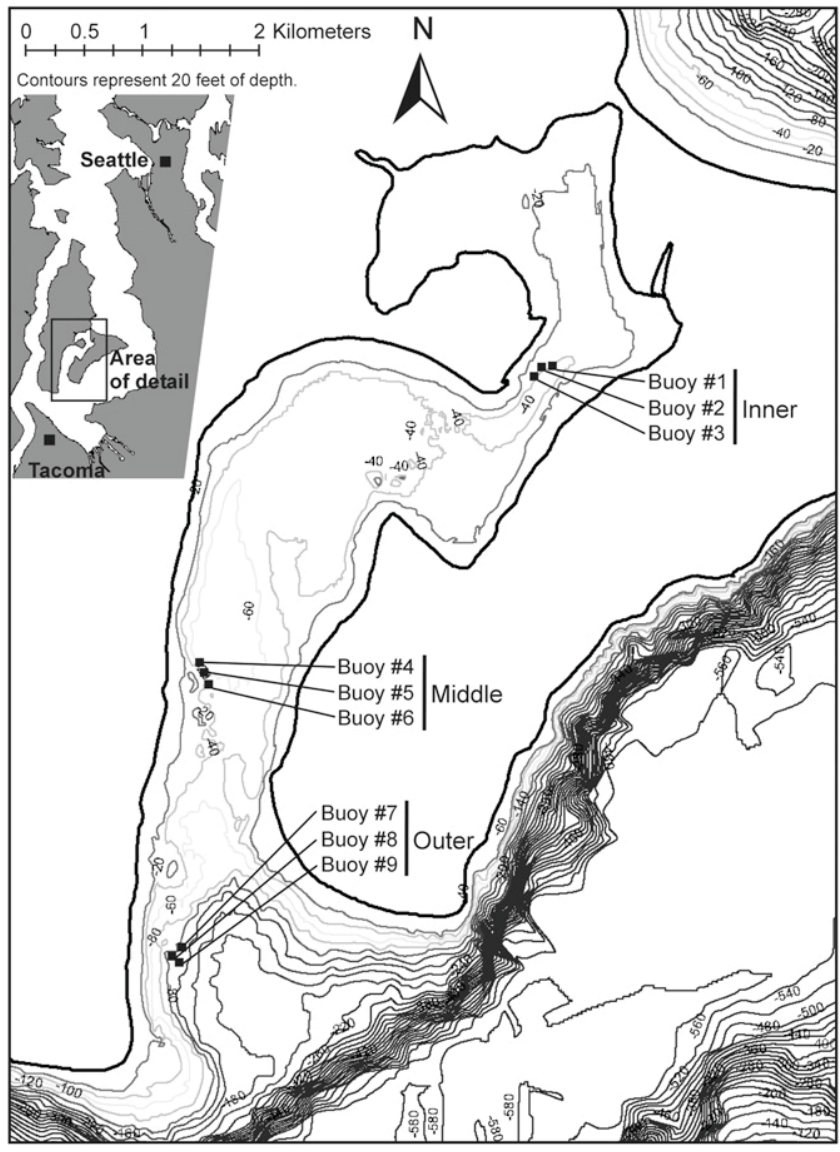

Figure 3. Map of larval geoduck sampling locations in Quartermaster Harbor, WA. The sampling design included 3 stations (Inner, Middle, and Outer), each with 3 replicate buoys. Each buoy contained traps at 3 depths.
Washington 1976). As a result of this geomorphology, water residence time in the inner QMH is quite long (University of Washington 1976).

This site was selected for the high probability of capturing geoduck larvae in this area because of the retentive nature of the hydrology and the existence of a large source population of adult geoduck in the outer section of QMH $(>4$ million individuals surveyed by Puyallup Tribe for the South Sound Geoduck Management Plan in 2002; D. Winfrey, Puyallup Tribe, pers. comm., February 6. 2012). It should be noted that there is not a significant population of adult geoduck in the muddy inner harbor. In addition, QMH was also chosen because of a large existing research program in the area that could provide supporting data for our study. This area is well studied as a result of longstanding concerns about water quality (University of Washington 1976), including low dissolved oxygen in the inner QMH in the summer (King County 2010) and the high number of cysts of the toxic dinoflagellate Alexandrium catenella found in QMH during a survey of Puget Sound in 2005 (Horner et al. 2011).

We established 3 replicate buoys at 3 stations in QMH at different distances into the harbor: inner (depth, 10-11 m), middle (depth, 14-15 m), and outer (depth, 34-36 m; Fig. 3). Traps were deployed at 3 depths: surface (approximately $1 \mathrm{~m}$ from the surface), $4 \mathrm{~m}$ (where the thermocline was expected to be (Nishitani \& Chew 1984)), and bottom (within $1 \mathrm{~m}$ of the seafloor; Fig. 2). Buoys consisted of a surface float, a subsurface float, and an anchor. This design kept our surface and 4-m traps at the same depth relative to the surface at all tidal levels. At the deeper outer buoys, traps were only placed at the surface and at $4 \mathrm{~m}$ because of the limited bottom time of the divers at the depth of those buoys. A temperature logger was placed near every trap and it collected temperature data every 30 min during deployment.

Traps were deployed on the buoys by scuba divers weekly from March 2 through June 8, 2010, with an additional week of sampling from July 7 through July 14. During every deployment and retrieval event, water column properties (temperature, salinity, fluorescence, and dissolved oxygen) were measured with a Seabird 19 CTD once in the middle of each sampling station (inner, middle, outer; Fig. 3). During 1 wk (March 23 to 31 ), pickup was delayed 1 day because of rough weather, and 1 sample (from $4 \mathrm{~m}$ ) was lost from the middle station.

Our goal was to examine geoduck distribution with sufficient spatial and temporal coverage given logistical constraints. We analyzed trap contents for all weeks sampled at the 3 replicate buoys in the middle station, where we expected to find the most geoduck. These samples represented a "temporal" data set, with limited spatial variation. In addition, we examined all stations for $1 \mathrm{wk}$ during the peak of reproduction (May 25 to June 1, 2010), as determined using our temporal data set, to analyze "spatial" patterns.

\section{Laboratory Processing}

As new traps were deployed, traps from the previous week were retrieved and taken back to the laboratory to be filtered and preserved. The contents of each tube were run through a $78-\mu \mathrm{m}$ filter (or a series of $310-\mu \mathrm{m}$ and $78-\mu \mathrm{m}$ filters, which were later combined, if the trap was particularly full of phytoplankton) and rinsed with filtered seawater at a salinity of 27. Samples were rinsed with seawater until all visible DMSO fixative had been removed. The sample was preserved using modified salt 
ethanol solution (MSE; 73\% ethanol, 17\% deionized water, and $10 \%$ SET buffer, $3.75 \mathrm{M} \mathrm{NaCl}, 25 \mathrm{mM}$ EDTA, 0.5 M Tris Base brought to $\mathrm{pH} 7.8$ with $\mathrm{HCl}$ ) (Goffredi et al. 2006).

FISH-CS was performed according to the methods of Henzler et al. (2010), with slight modifications for the volume of the samples collected during this study. Samples stored in MSE were permeabilized by adding $12 \mathrm{~N} \mathrm{HCl}(1 \% \mathrm{w} / \mathrm{v})$ and agitating at room temperature for $10 \mathrm{~min}$. Samples were then poured into a hybridization net that was fabricated from a 5.5-cm-inner diameter embroidery hoop and a piece of $30-\mu \mathrm{m}$-mesh plankton net. Each sample was rinsed with freshly prepared $5 \times$ SET hybridization buffer (5× SET, 0.1\% IGEPAL-CA630; modified from Miller \& Scholin (2000)) and inserted into the hybridization chamber by placing the embroidery hoop on the lip of a $5.5-\mathrm{cm}$ glass dish. Twenty milliliters of the $5 \times$ SET hybridization buffer was added to the dish so that the sample was submerged, and the whole apparatus was placed inside a small Rubbermaid container to minimize evaporation. The sample was prehybridized at $55^{\circ} \mathrm{C}$ for $30 \mathrm{~min}$ with agitation before the TET-labeled probe was added at a concentration of $5 \mathrm{ng} / \mu \mathrm{L}$. Samples were hybridized with the probe for $3 \mathrm{~h}$ at $55^{\circ} \mathrm{C}$ with agitation, and then washed 3 times in $1 \times \mathrm{SET}$ for $10 \mathrm{~min}$ at $55^{\circ} \mathrm{C}$ with agitation. Before cell sorting, the hybridization net was disassembled carefully and the sample was rinsed from the net with DI water into a $250-\mathrm{mL}$ beaker.

Larvae were sorted with a COPAS Plus cell sorter (Union Biometrica) with a $1 \times 1-\mathrm{mm}$ square flow cell and a $488-\mathrm{nm}$ laser. The baseline ratio of yellow to green autofluorescence was determined from control plankton samples. A sorting region was chosen to select particles with a ratio of yellow to green fluorescence greater than the control, indicating these particles were marked with the TET-labeled probe, which fluoresces in the yellow part of the spectrum when excited with the $488 \mathrm{~nm}$ laser. Particles that met the sorting criteria, including geoduck larvae and some other particles and detritus, were dispensed into a glass dish. The sorted particles were then examined under a dissecting microscope, where the bivalve larvae were counted and reserved for further analysis. A few samples were discarded during validation as a result of sampling anomalies: from week March 23 to 31, 1 each from the surface and from $4 \mathrm{~m}$; and week April 20 to 27, 2 surface and 1 from $4 \mathrm{~m}$.

To verify that bivalve larvae sorted from the plankton samples were indeed geoducks, DNA was extracted individually from a subset of sorted larvae using the protocol of Gloor et al. (1993). Geoduck-specific PCR primers (targeting 18S of both P. generosa and P. globosa; forward 5'-CCGCACACGCGCT ACACTGA-3' and reverse 5' -TCGGCACGCCAGAGAGCA GA-3') were developed and tested against the same 17 species used in the dot blot to verify specificity. The universal $18 \mathrm{~S}$ primers that amplified robustly a small $(\sim 380$-bp) $18 \mathrm{~S}$ fragment in all the species of bivalves for the dot blot were used as a positive control. Successful amplification with the geoduck primer set for 97 of the larvae verified that they were geoducks; putative geoduck larvae that failed to amplify also failed to amplify with the positive control universal primers. The small size of the larvae, the process of FISH-CS, and subsequent handling to measure the larvae may have reduced the amount of usable DNA below a detectable threshold in some of the larvae. After geoducks had been removed by FISH-CS, the remainder of 10 samples were examined under a dissection microscope to identify any remaining bivalves. A total of 14 bivalve larvae were found, all of which were identified as geoducks using the geoduck-specific $18 \mathrm{~S}$ primers $(9$ of the 10 samples had 3 or fewer geoducks that were missed by sorting, and a single sample had 7). Because the average sample had more than 100,000 particles, FISH-CS has a negligible false-positive rate and a low false-negative rate.

Recovered larvae that were not damaged during processing were measured individually. Larvae were pipetted into a SedgwickRafter counting slide, covered with a slip, and photographed under $100 \times$ power on a compound microscope. They were then measured using Infinity Analyze software (Lumenera Corporation) after calibration with a stage micrometer. Length was considered the longest axis of the shell.

\section{Statistical Analysis}

Statistical analyses were performed to assess both spatial and temporal variation in geoduck larval abundance. Spatial analyses used data from all buoys and depths from a single week (May 25 to June 1). A 2-way analysis of covariance (ANCOVA) was run to test for variation in relative larval abundance with location (inner, middle, and outer harbor) and depth (surface, $4 \mathrm{~m}$, and bottom) while controlling for proportional water flow. Post hoc sequential Bonferroni-corrected individual contrasts were performed to test for variation among locations and depths (Rice 1989).

Temporal analyses used data from all weeks and depths for buoys in the middle harbor station to determine what factors were associated with temporal variation in relative larval abundance. A general linear model (GLM) was produced to predict larval abundance based on salinity, temperature, dissolved oxygen, fluorescence, stratification index, depth, and proportional water flow as independent variables. Stratification index was calculated by determining the maximum slope of density (sigma- $t$ ) with depth for each CTD cast. Depth and water flow were included in the model as covariates as a result of the significant relationship between depth and relative larval abundance in the spatial analysis and because of the potential for water flow to affect capture efficiency. Analyses of relative abundance were performed using a natural $\log$ plus 1 transformation to meet the assumptions of the analyses.

Variation in the size of larvae among months and depths in the temporal data set was determined using 2-sample KolmogorovSmirnov (KS) tests using sequential months or depths as groups in the analyses. Spatial variation in the size of larvae was also determined using KS tests. To determine whether the size distribution of larvae varied with depth in the spatial data set, surface samples from all stations were combined and compared with the 4-m samples. Bottom samples were not analyzed because of the small sample sizes in this data set. To determine whether the size distribution of larvae varied among locations, stations were compared combining data across all depths. Sequential Bonferroni corrections were performed on KS results to control type I error rates resulting from multiple tests (Rice 1989). Spatial and temporal abundance analyses were performed utilizing JMP (SAS Institute, 2004), and size analyses were performed utilizing R Statistics (R Development Core Team, 2011).

\section{RESULTS}

\section{Spatial and Temporal Distribution of Larvae}

We captured and identified more than 2,000 geoduck larvae throughout the sampling period and at all stations and depths. Using the middle station, variation in relative geoduck larval 
abundance was examined through time. We observed 1 small and 1 large peak in abundance during our sampling period (Fig. 4), the former in March, during our first 3 or $4 \mathrm{wk}$ of sampling, and the latter toward the end of the season (beginning in late May), peaking in the first week of June, which was our last week of weekly sampling. When we returned to do a monthly sample in early July, the relative abundance at the thermocline dropped, although there were still approximately the same number of larvae at the surface.

We examined horizontal and vertical spatial variation across all stations for a week during the larval peak (May 25 to June 1). There was significant variation in the relative abundance of geoduck larvae among stations (Table 1, Fig. 5) with the inner and middle stations having greater relative abundances than the outer station $\left(\mathrm{F}_{1,18}=11.345, P=0.003\right)$. Samples from different depths during this week were compared across all stations (Fig. 5), and although the differences among depths were only marginally significant (Table 1), the shallow depths tended to have higher relative abundances compared with the bottom. This lack of significance is driven primarily by the smaller number of samples, the high variation among samples at a given depth, and the need to control for increased flow at the surface. The vertical distribution pattern in larval abundance was also detected in the temporal data set, with the bottom traps consistently catching significantly fewer larvae than those at the surface and at $4 \mathrm{~m}$ $\left(\mathrm{F}_{1,108}=8.661, P=0.004\right.$; Fig. 4). The location $\times$ depth interaction was not included in the final spatial analysis because of a nonsignificant effect $\left(\mathrm{F}_{3,15}=0.952, P=0.440\right)$.

\section{Association of Larvae with Physical Variables}

Flow was highly variable in space and time, with higher flows earlier during the sampling period $\left(R^{2}=0.177, \mathrm{~F}_{1,345}=74.081\right.$,

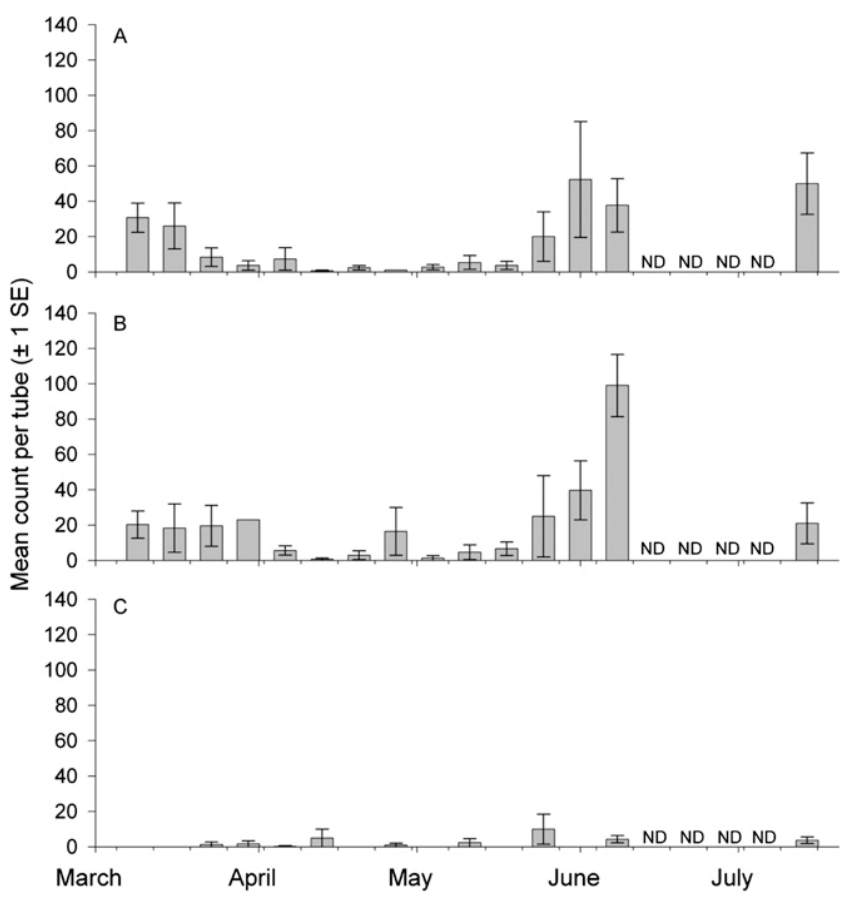

Figure 4. Mean number $( \pm \mathrm{SE})$ of geoduck larvae per tube per week during the sampling period from March 9, 2010, to July 17, 2010, for the Middle station in Quartermaster Harbor. (A) Surface tube, depth of $1 \mathbf{~ m}$. (B) Tube at depth of $4 \mathrm{~m}$. (C) Bottom tube at depth of $15 \mathrm{~m}$. ND, no data.
TABLE 1.

ANCOVA of spatial analysis.

\begin{tabular}{lrcccc}
\hline \hline \multicolumn{1}{c}{ Effect } & $\boldsymbol{d} \boldsymbol{f}$ & MSE & F Ratio & $\boldsymbol{P}$ Value & $\boldsymbol{R}^{\mathbf{2}}$ \\
\hline Relative flow & 1 & 0.790 & 1.068 & 0.315 & 0.056 \\
Location & 2 & 4.195 & 5.673 & 0.012 & 0.387 \\
Depth & 2 & 2.025 & 2.739 & 0.092 & 0.233 \\
Error & 18 & 0.739 & & & \\
\hline
\end{tabular}

Spatial analysis (all stations for $1 \mathrm{wk}$ ) statistical details from the ANCOVA. MSE, mean squared error.

$P<0.001)$, declining with depth $\left(R^{2}=0.354, \mathrm{~F}_{1,345}=189.113\right.$, $P<0.001)$ and increasing from the inner to outer stations $\left(R^{2}=\right.$ $0.100, \mathrm{~F}_{2,345}=19.206, P<0.001$; Fig. 6). When looking across all our sampling points, the association between flow and larval capture was significant but weak $\left(R^{2}=0.066, \mathrm{~F}_{1,138}=9.752\right.$, $P=0.002)$. If larval capture rates were driven primarily by water flow patterns, we would have predicted higher capture at the beginning of sampling at the surface and increasing from the inner to outer harbor. Although we captured more larvae in the faster moving surface waters, we captured fewer in the outer station and during times when flow was higher. Therefore, although flow may have influenced capture efficiency, it is unlikely to have been the primary driver of capture rates.

During the first 2 mo of sampling (March and April), the water column was relatively well mixed, with the exception of 2 wk in late March when a weak thermocline and halocline were detected followed by a mixing event (Fig. 7). The water column became increasingly stratified beginning in May through early summer. For much of late April and early May, QMH experienced a large bloom of diatoms that began at the surface and gradually sank toward the bottom. This was also a period of relatively low geoduck larval abundance.

The spatial and temporal distribution of larvae showed little correlation with measured physical variables (Fig. 7, Table 2).

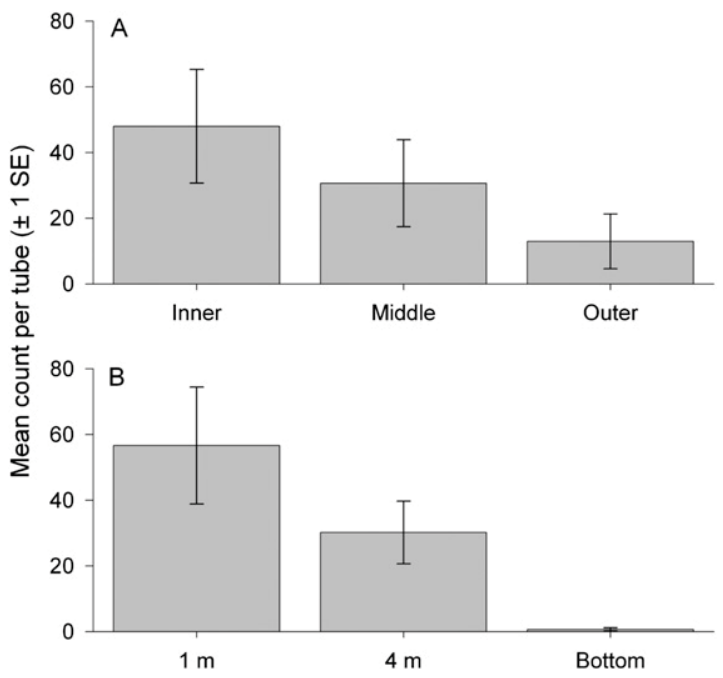

Figure 5. Mean number $( \pm S E)$ of geoduck larvae per tube during the sampling period from May 25, 2010, to June 1, 2010, across all stations in Quartermaster Harbor. (A) Mean number of geoduck larvae at the various sampling locations. (B) Mean number of geoduck larvae at the various sampling depths. 


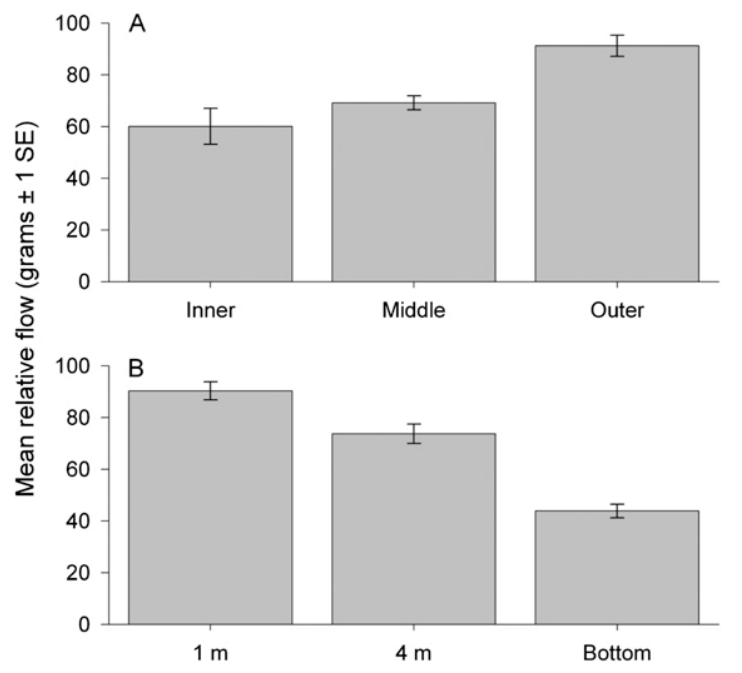

Figure 6. Mean relative flow $( \pm \mathrm{SE})$ as measured by dissolution of calcium sulfate pucks (in grams) during the sampling period from May 25, 2010, to June 1, 2010, across all stations in Quartermaster Harbor. Data were included to correspond with larval abundance data. (A) Mean relative water flow at the various sampling locations. (B) Mean relative water flow at the various sampling depths.

The temporal model (GLM) explained $39 \%$ of the variation in relative abundance of geoduck larvae $\left(F_{7,109}=10.057\right.$, $P<0.001)$; however, few of the independent variables showed significant associations with relative larval abundance (Table 2). Relative flow and depth were associated marginally with larval abundance, but these variables were included primarily as covariates in the model because it was assumed they would influence larval capture. Only stratification index was associated significantly with relative abundance of geoduck larvae (Table 1), and this variable explained $16 \%$ of the variation in relative larval abundance. At higher stratification indices (i.e., the water column becomes more stratified), there was an increase in the relative abundance of larvae. Variation in geoduck relative larval abundance was not associated significantly with variation in salinity, temperature, dissolved oxygen, or fluorescence.

\section{Size Distribution of Geoduck Larvae}

A total of 835 individuals were measured for the temporal data set (middle station), and 540 were measured for the spatial data set (May 25 to June 1). The smallest larva was $91 \mu \mathrm{m}$ wide and $94 \mu \mathrm{m}$ long, whereas the largest was $325 \mu \mathrm{m}$ by $437 \mu \mathrm{m}$. These values are consistent with larval sizes reported by Goodwin et al. (1979).

The size-frequency distributions of larvae varied at the middle station between sequential months (Fig. 8). Larvae had significantly different size-frequency distributions between March and April ( $\mathrm{D}=0.341, P=0.005)$, April and May $(\mathrm{D}=$ $0.288, P=0.008)$, May and June $(\mathrm{D}=0.350, P<0.001)$, and June and July $(\mathrm{D}=0.233, P<0.001)$. It should be noted that the number of larvae measured each month varied, especially in April (46 individuals), so the height of the peaks in Figure 8 are not directly comparable. In addition, size-frequency distributions varied with the depth that the larvae were captured. Larvae had significantly different size-frequency distributions between the surface and $4 \mathrm{~m}(\mathrm{D}=0.222, P<0.001)$, and between $4 \mathrm{~m}$ and the bottom $(\mathrm{D}=0.301, P=0.011)$. The sizefrequency distribution of larvae from the surface did not differ from those at the bottom ( $\mathrm{D}=0.197, P=0.169)$.

When investigating 1 sampling week (May 25 to June 1), spatial patterns in size-frequency distribution exist across stations and depths (Fig. 9). Larvae had significantly different size-frequency distributions between the inner and outer stations $(\mathrm{D}=0.352, P<0.001)$ and the middle and outer stations (D $=0.324, P<0.001)$. The size-frequency distribution of larvae from the inner station did not differ from that at the middle station $(\mathrm{D}=0.084, P=0.650)$. Larvae captured at the surface had a significantly different size-frequency distribution than those captured at the thermocline $(\mathrm{D}=0.191, P<0.001)$.

\section{DISCUSSION}

\section{Utility of the Sampling Approach}

We used a novel approach successfully - FISH-CS with larval trapping - to capture, identify, quantify, and measure geoduck larvae in situ. These findings represent the first published record of wild geoduck larvae that we are aware of, and are the first published field application of the FISH-CS method (Henzler et al. 2010). FISH-CS allowed geoducks to be identified and sorted from samples rapidly. This approach is unique because it is largely automated, allowing high throughput, and most larvae are not destroyed during processing, allowing for further study of each individual. FISH-CS performed well, identifying and sorting geoduck larvae successfully from bulk plankton samples with low error. The biggest challenge in these field-collected samples compared with laboratory trials was the samples collected during the diatom bloom, because large clumps of diatoms clogged the cell sorter, slowing the sorting process. This study demonstrates that FISH-CS is an effective tool for sorting plankton samples quickly and accurately for a species of interest.

Although FISH-CS improved the efficiency of sorting and identifying samples dramatically, collecting larvae at the right time and place remained a significant challenge, especially for geoducks, which had not been sampled previously in the field. Our passive trap design allowed for a time-integrated sample of the water column and avoided the problem of missing a transient pulse of larvae.

The passive tube traps functioned well in this estuarine environment. Although water flow is an inherent and potentially confounding component of our capture rates, there are a number of reasons why our patterns of larval distribution are presumably robust. Most important, relative water flow was used as a covariate in our analyses of the significance of distribution patterns. In addition, 2 of our 3 patterns, the horizontal and temporal larval distributions, were correlated negatively with relative water flow. Therefore, the underlying abundance patterns could possibly be stronger than those recorded here. The distribution of larvae with depth was correlated positively with flow, and could have made our patterns with depth appear larger, although in the spatial analysis when the effect of flow was removed, patterns with depth were still moderately significant. Our analysis was therefore conservative in terms of detecting an effect of depth on relative larval abundance. It should be noted that water flow was about twice as fast in surface waters than at the bottom, and larval capture was about 10 times greater at the 2 surface traps than the bottom, on average. 

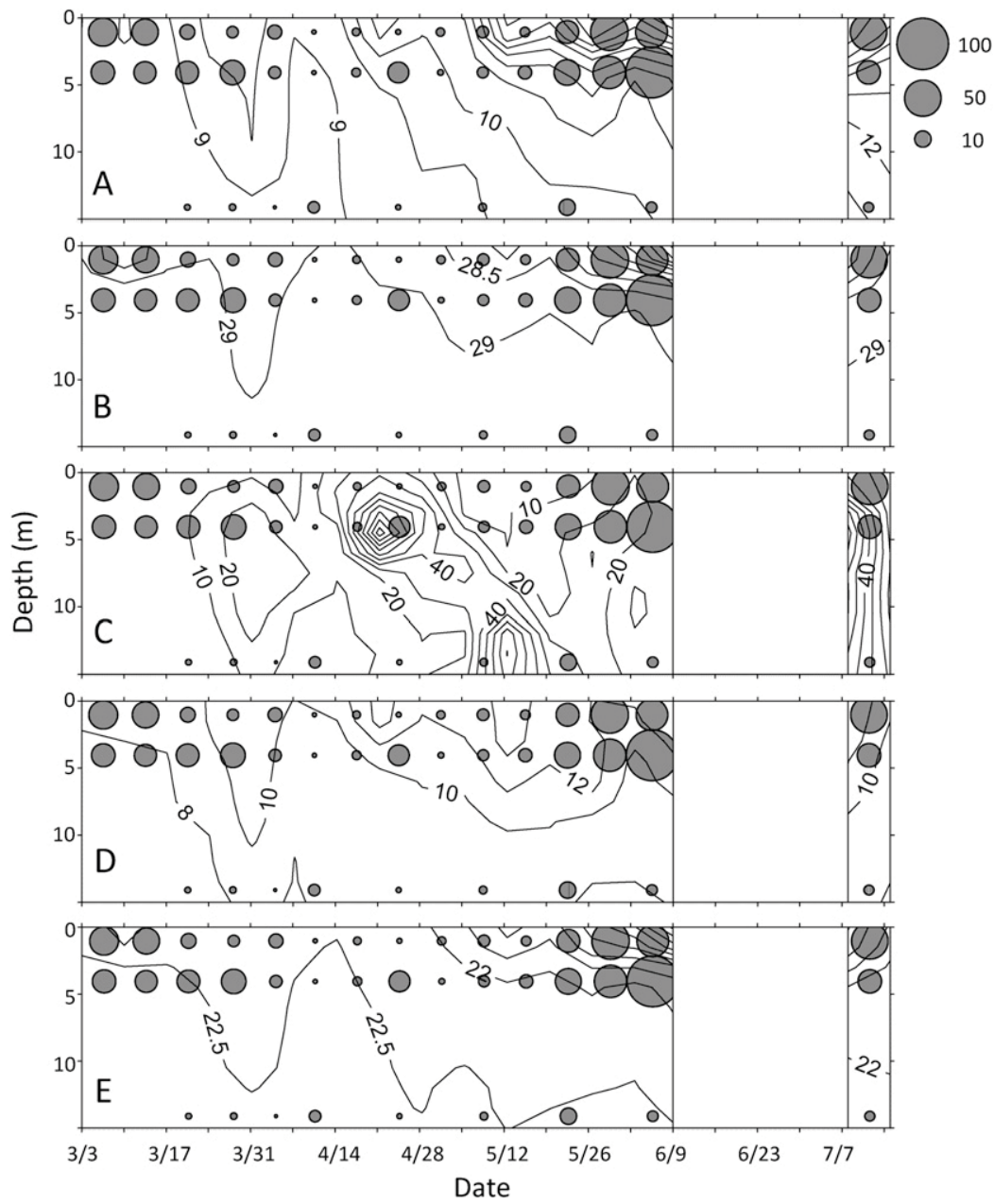

Figure 7. Physical parameters measured weekly via CTD at the middle station in Quartermaster Harbor from March 9, 2010, to July 17, 2010. (A) Temperature (measured in degrees Celsius). (B) Salinity. (C) Fluorescence (measured in milligrams per square meter). (D) Dissolved oxygen (measured in milligrams per liter). (E) Density (measured in sigma-t). Size of bubbles represents average number of larvae captured per trap during the week between the CTD casts at a given depth.

There have been 3 additional relevant criticisms of using passive tube traps to determine relative larval abundance. The first is that traps are biased by dead larvae falling vertically through the water column. It should be noted that if our

TABLE 2.

General linear model of temporal analysis.

\begin{tabular}{lrrrrc}
\hline \hline \multicolumn{1}{c}{ Effect } & $\boldsymbol{d} \boldsymbol{f}$ & MSE & F Ratio & $\boldsymbol{P}$ Value & $\boldsymbol{R}^{\mathbf{2}}$ \\
\hline Relative flow & 1 & 2.986 & 2.284 & 0.134 & 0.021 \\
Depth & 2 & 10.157 & 7.771 & 0.001 & 0.126 \\
Stratification index & 1 & 18.671 & 14.286 & $<0.001$ & 0.117 \\
Salinity & 1 & 1.584 & 1.212 & 0.273 & 0.011 \\
Temperature & 1 & 0.291 & 0.223 & 0.638 & 0.002 \\
Dissolved oxygen & 1 & 1.576 & 1.206 & 0.275 & 0.011 \\
Fluorescence & 1 & 0.309 & 0.237 & 0.628 & 0.002 \\
Error & 108 & 1.307 & & & \\
\hline
\end{tabular}

Temporal analysis (1 station for all weeks) statistical details from the general linear model. MSE, mean squared error. samples were biased by vertically falling larvae, we would predict higher capture at deeper traps; we saw the opposite pattern. In addition, larvae that died prior to preservation are not well marked by the probe (probably because of the rapid degradation of $18 \mathrm{~S}$ rRNA), and therefore were not counted by our method. Second, Butman (1986) reported that particle size can affect capture in tube traps, with capture increasing with size, although in this case the researcher used particles 5-10 times smaller than our larvae. Because of this potential bias, our size data were only analyzed statistically as distributions, with the potential for sample bias toward larger sizes, although we assessed average sizes qualitatively. Third, Beaulieu et al. (2009) found that pumped and trapped larval samples did not correlate in the deep sea and that traps caught weaker swimming species preferentially. Our analysis examined relative supply of a single species, so this potential bias should not affect our results. Given the potential biases among the larval sampling options, traps were a good choice to maximize the spatial coverage and temporal integration needed to capture a patchy population that was present at an unknown time. 


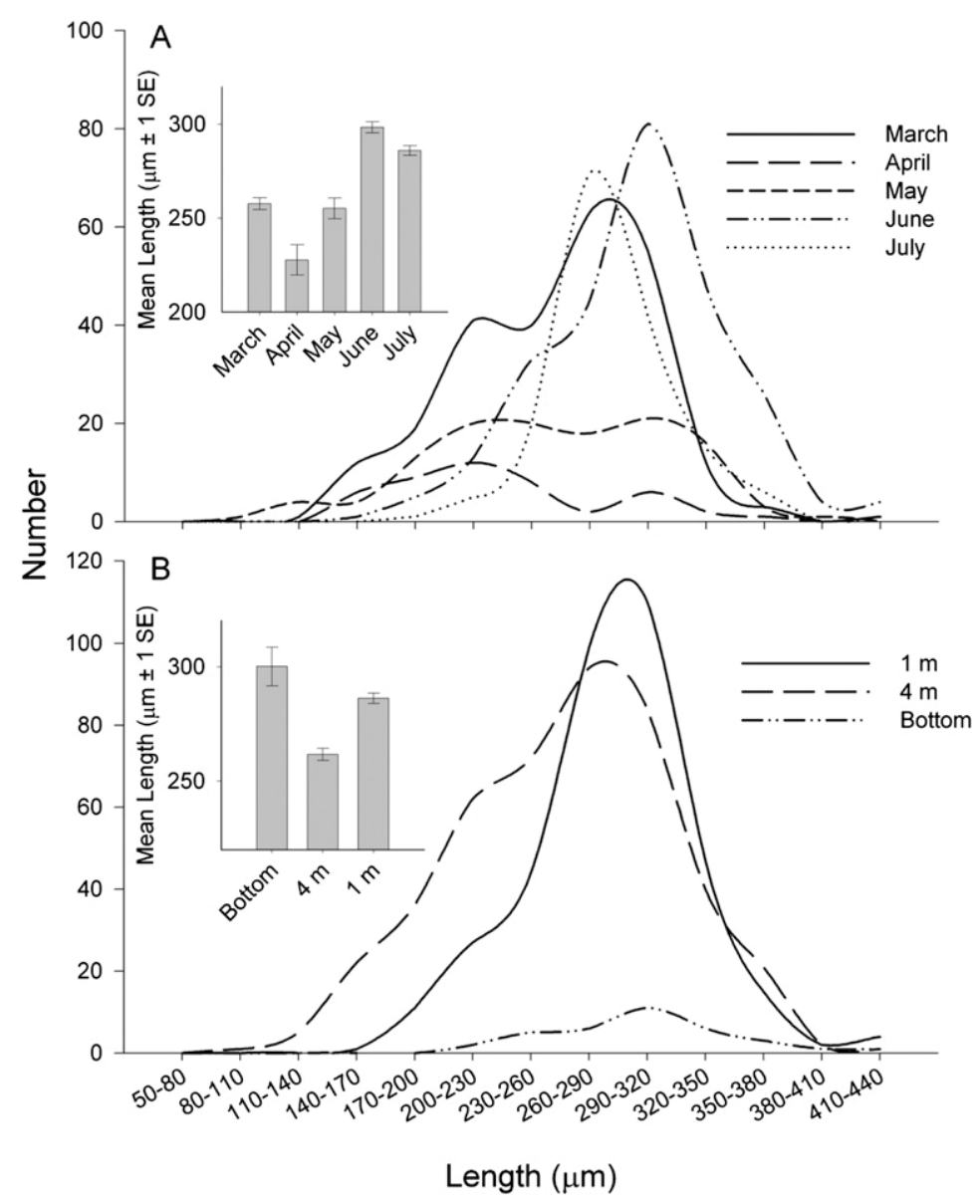

Figure 8. Size-frequency distributions of larvae caught at the middle station buoys in Quartermaster Harbor. (A) Size-frequency distributions and average size $( \pm$ SE) by month for all depths combined. March $(n=247)$, April $(n=46)$, May $(n=121)$, June $(n=260)$, and July $(n=161)$. (B) Sizefrequency distribution and average size $( \pm \mathrm{SE})$ by depth for all months combined. $1 \mathrm{~m}, n=360 ; 4 \mathrm{~m}, n=440$; and bottom, $n=35$.

\section{Distribution and Size of Geoduck Larvae in Quartermaster Harbor}

Geoduck larvae were not evenly distributed throughout QMH. More were found in the inner and middle stations than at the mouth of the harbor, despite the fact that the adults are found in the outer and middle sections. It is possible that at least some of the larvae are entrained in the slow-moving inner waters and remain there throughout their planktonic larval duration. This hypothesis that larvae are retained in the inner harbor is supported by the size-frequency distribution of larvae across all stations in late May and early June, as more large larvae are found in the inner harbor than at the mouth. This indicates that QMH populations might also show signs of restricted gene flow like those in Freshwater Bay (Vadopalas et al. 2004). More work would need to be done to validate this possible scenario. These existing distribution data, which include variance on scales less than $10 \mathrm{~km}$, could be used to parameterize realistic models of geoduck dispersal that would explore this pattern further.

Previous work with bivalves has demonstrated that larvae can orient themselves in response to various stimuli (reviewed by Kingsford et al. (2002)), allowing for vertical migration on diurnal or tidal timescales. Geoduck larvae appear to be located near the surface of the water column with no evidence of vertical migration on long or short timescales, although we did not assess this directly with our method. Our traps were deployed throughout a full week, and continued to sample during all parts of the tidal and diurnal cycles. If larvae were migrating vertically on these timescales, we would have expected to find more larvae near the bottom. In our study, more larvae were found consistently at the surface or near the usual depth of the thermocline $(4 \mathrm{~m})$ than at the bottom, indicating that larvae were not spending time in deeper waters. More work needs to be done to validate this pattern using targeted studies.

In addition, there were no clear patterns indicating ontogenetic migration in our samples. There were significant differences between the size of larvae at the surface and the thermocline, although when looking at 1 site across all weeks, the surface larvae were marginally larger; when looking at all stations in a single week, the surface larvae were marginally smaller. Although there was no significant difference in size distribution among surface and bottom larvae, there was a lack of small larvae captured and, therefore, an apparent larger average size in the bottom traps. Our largest larvae were within the expected range for metamorphosis and settlement (average length at metamorphosis was $380 \mu \mathrm{m}$ according Goodwin et al. (1979)), and were not found to be concentrated toward the bottom (Fig. 8).

Numerous studies have found a relationship between bivalve larvae and various environmental variables (reviewed by 


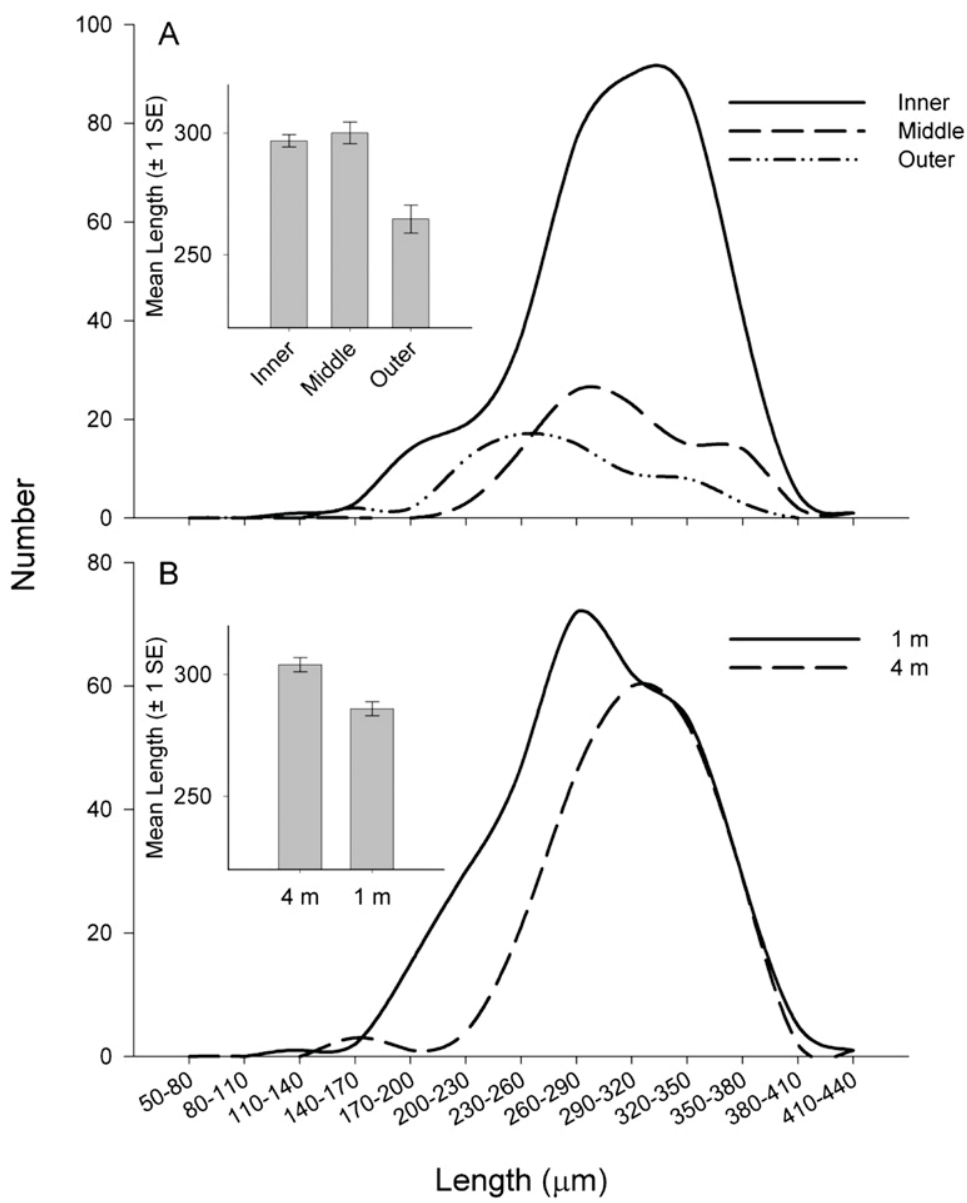

Figure 9. Size-frequency distributions and average size ( \pm SE) of larvae caught during the week of May 25 to June 1, 2010 in Quartermaster Harbor, WA. (A) Size-frequency distributions and average size $( \pm$ SE) by station for all depths combined. Inner $(n=374)$, Middle $(n=98)$, and Outer $(n=68)$. The middle station included buoys 4 and 6 , because larvae caught at buoy 5 were destroyed to confirm FISH-CS accuracy. (B) Size-frequency distribution by depth for all stations combined. $1 \mathrm{~m}, n=319$; and $4 \mathrm{~m}, n=221$ ). Bottom samples were excluded because of extremely low sample sizes.

Kingsford et al. (2002)), such as food patches, dissolved organic matter, and salinity (e.g., Dobretsov \& Miron 2001). The majority of the physical variables we measured, such as temperature, salinity, dissolved oxygen, and fluorescence, were not associated with relative geoduck larval abundance. Besides relative water flow (discussed earlier), the only factor that correlated significantly with larvae was degree of stratification. Larvae may have been concentrated directly by stratification or by biological factors during the period of increasing stratification.

Geoduck larvae were found throughout the assumed reproductive season (March through July), and appeared to peak in March and, to a greater extent, in late May or early June. It is notable that we captured larvae during our first week of sampling in early March, indicating that spawning occurred earlier in February, as well as during our last week in mid July, indicating that the reproductive season could extend later into the summer than expected. When the size-frequency distribution for the middle station is examined by month, there appears to be at least 2 separate cohorts in our larval population that correspond to the 2 peaks noted in the larval count data. In March, the size distribution appears bimodal, with a peak of smaller larvae $(\sim 200-230 \mu \mathrm{m})$ and larger larvae $(\sim 260-320 \mu \mathrm{m})$. These 2 peaks are still present in April, although shifted slightly toward larger sizes and considerably fewer in number. The 2 peaks are still present in May. In June, there appears to be a peak of relatively large larvae $(\sim 260-320 \mu \mathrm{m})$ in QMH. Given the generally much higher capture rates in June, it is possible that these larvae were imported into QMH at this time, because there does not seem to be a corresponding number of smaller larvae in our samples; however, we cannot exclude the possibility that these larvae developed elsewhere in QMH where we did not sample. In July, there was a peak of larvae of smaller size than in June. This indicates that the larvae captured in June were no longer in the water column and we might have captured an additional cohort, although because we only sampled 1 wk between June 8 and July 14, it is difficult to draw further inferences. We are using size as a proxy for larval age, although as a result of exposure to different conditions in the water column, growth rates could vary among individuals (Hadfield \& Strathmann 1996). Given the warmer temperatures experienced by larvae later in the season, their growth rates could be considerably faster making a large larvae younger than one of a similar size captured earlier in the season. 


\section{Management Implications}

Washington state accounts for the majority of the U.S. geoduck harvest, both commercial (National Marine Fisheries Service 2010) and farmed (Pacific Coast Shellfish Growers Association 2009). According to the Washington Department of Fish and Wildlife (2011), wild commercial harvest of geoduck in 2010 was more than 1.9 million $\mathrm{kg}$ (including shells), worth more than $\$ 36$ million. In addition, more than $725,000 \mathrm{~kg}$, valued at almost $\$ 63$ million, were produced through aquaculture in the state (Pacific Coast Shellfish Growers Association 2009). Most geoduck growers out-plant hatchery-raised juveniles rather than rely on natural recruitment as their source of new production. There is significant concern in Washington state about the effects of geoduck farming on wild populations, and a need to learn more about their larval ecology in situ. Our sampling approach can be applied to explore this question directly.

Management of wild geoduck populations requires a longterm and interdisciplinary strategy. Geoduck are particularly long-lived (100+ years) and do not reach maturity for at least 2-3 y (Campbell \& Ming 2003). This, combined with their high fecundity, means they may be able to maintain populations in the face of changing conditions through the success of relatively rare but large recruitment pulses when conditions are optimal, despite little or no recruitment in other years (Straus et al. 2008). A number of studies have looked at long-term recruitment patterns in geoduck using size-frequency distributions of aged adults, and have found a long-term decline in recruitment from 1920 to 1975 , with an increase through the 1990s (Valero et al. 2004). These data have been useful for recommending precautionary harvest rates (Zhang \& Hand 2006). Given the long timescale of the geoduck life cycle and the degree of harvest sustained by populations, a possible geoduck recruitment failure would take years to detect using adult age-frequency distributions, but might be caught earlier if larval abundance or settlement is measured directly. Much remains unknown about their prerecruitment development, including larval life history and settlement rates. In addition to population genetics and adult surveys, quantifying and monitoring these early processes in space and time is an important part of adaptively managing this commercially and culturally important species. Empirically determined larval distribution data, like those we have collected in this study for Puget Sound geoduck clams, are crucial for modeling the effects of various management strategies accurately.

\section{ACKNOWLEDGMENTS}

We thank J. Hill (Tacoma SCUBA), J. Barney (Citizens for a Healthy Bay), S. Gaines (University of California Santa Barbara; UCSB), D. Behrens, E. Jones (Taylor Shellfish), B. Vadopalas (University of Washington; UW), C. Grammlich (San Diego State University), C. Farfán (El Centro de Investigación Científica y de Educación Superior de Ensenada), P. Valentich-Scott (Santa Barbara Museum of Natural History), as well as many UW Tacoma, Pacific Lutheran University, and UCSB students, faculty, and staff: A. Moore, E. J. Rauschl, S. Staggers, J. Brokenshire, J. Patterson, J. Roach, S. Troyer, M. Maltese, J. Gruber, J. Chang, S. Ayers, K. Baird, K. Reneman, B. Compton, C. Greengrove, J. Masura, P. Selkin, L. Wetzstein, J. Asplund, M. Orlando, C. Kuwata, and J. Wang. Funding was provided by the UWT Chancellors Fund for Research and the UW Royalty Research Fund. The manuscript was improved by comments from L. Levin, B. Vadopalas, C. Greengrove, E. Cline, and 2 anonymous reviewers.

\section{LITERATURE CITED}

Arellano, S. M. \& C. M. Young. 2010. Pre- and post-settlement factors controlling spatial variation in recruitment across a cold-seep mussel bed. Mar. Ecol. Prog. Ser. 414:131-144.

Bayne, B. 1976. Marine mussels, their ecology and physiology. Cambridge, UK: Cambridge University Press. 576 pp.

Beaulieu, S. E., L. S. Mullineau, D. K. Adams \& S. W. Mills. 2009. Comparison of a sediment trap and plankton pump for time-series sampling of larvae near deep-sea hydrothermal vents. Limnol. Oceanogr. Methods 7:235-248.

Becker, B. J., L. A. Levin, F. J. Fodrie \& P. A. McMillan. 2007. Complex larval connectivity patterns among marine invertebrate populations. Proc. Natl. Acad. Sci. USA 104:3267-3272.

Bousfield, E. L. 1955. Ecological control of the occurrence of barnacles in the Miramichi Estuary. Natl. Mus. Can. Bull. Biol. Ser 137:1-65.

Butman, C. 1986. Sediment trap biases in turbulent flows: results from a laboratory flume study. J. Mar. Res. 44:645-693.

Campbell, A. \& M. Ming. 2003. Maturity and growth of the pacific geoduck clam, Panopea abrupta, in southern British Columbia, Canada. J. Shellfish Res. 22:85-90.

Carriker, M. 1951. Ecological observation on the distribution of oyster larvae in New Jersey estuaries. Ecol. Monogr. 21:19-38.

Carson, H. S., P. C. Lopez-Duarte, L. Rasmussen, D. Wang \& L. A. Levin. 2010. Reproductive timing alters population connectivity in marine metapopulations. Curr. Biol. 20:1926-1931.

Castilla, J. \& M. Varas. 1998. A plankton trap for exposed rocky intertidal shores. Mar. Ecol. Prog. Ser. 175:299-305.
Coan, E. V., P. Valentich Scott \& F. R. Bernard. 2000. Bivalve seashells of western North America: marine bivalve mollusks from Arctic Alaska to Baja California, $1^{\text {st }}$ edition. Santa Barbara, CA: Santa Barbara Museum of Natural History. 764 p.

Comtet, T., D. Jollivet, A. Khripounoff, M. Segonzac \& D. Dixon. 2000. Molecular and morphological identification of settlementstage vent mussel larvae, Bathymodiolus azoricus (Bivalvia: Mytilidae), preserved in situ at active vent fields on the mid-Atlantic ridge. Limnol. Oceanogr. 45:1655-1661.

Cowen, R. K. \& S. Sponaugle. 2009. Larval dispersal and marine population connectivity. Annu. Rev. Mar. Sci. 1:443-466.

Cronin, T. \& R. Forward. 1979. Tidal vertical migration: endogenous rhythm in estuarine crab larvae. Science 205:1020-1022.

Dobretsov, S. \& G. Miron. 2001. Larval and post-larval vertical distribution of the mussel Mytilus edulis in the White Sea. Mar. Ecol. Prog. Ser. 218:179-187.

Dudas, S. E., G. Rilov, J. Tyburczy \& B. A. Menge. 2009. Linking larval abundance, onshore supply and settlement using instantaneous versus integrated methods. Mar. Ecol. Prog. Ser. 387:81-95.

Fairweather, P. 1991. Implications of supply-size ecology for environmental assessment and management. Trends Ecol. Evol. 6:6063.

Fiksen, O., C. Jorgensen, T. Kristiansen, F. Vikebo \& G. Huse. 2007. Linking behavioural ecology and oceanography: larval behaviour determines growth, mortality and dispersal. Mar. Ecol. Prog. Ser. 347:195-205. 
Gaines, S. \& M. Bertness. 1993. The dynamics of juvenile dispersal: why field ecologists must integrate. Ecology 74:2430-2435.

Gloor, G., C. Preston, D. Johnsonschlitz, N. Nassif, R. Phillis, W. Benz, H. Robertson \& W. Engels. 1993. Type-I repressors of P-element mobility. Genetics 135:81-95.

Goffredi, S., W. Jones, C. Scholin, R. Marin \& R. Vrijenhoek. 2006. Molecular detection of marine invertebrate larvae. Mar. Biotechnol. (NY) 8:149-160.

Goodwin, C. 1976. Observations of spawning and growth of subtidal geoducks. Proc. Natl. Shellfish. Assoc. 65:49-58.

Goodwin, C. \& B. Pease. 1989. Species profiles: life histories and environmental requirements of coastal fishes and invertebrates (Pacific Northwest): Pacific geoduck clam. U.S. Fish and Wildlife Service biological report 82(11.120). Vicksburg, MS: U.S. Army Corps of Engineers. 14 pp.

Goodwin, C., W. Shaul \& C. Budd. 1979. Larval development of the geoduck clam (Panopea generosa, Gould). Proc. Natl. Shellfish Assoc. 69:73-76.

Hadfield, M. \& M. Strathmann. 1996. Variability, flexibility and plasticity in life histories of marine invertebrates. Oceanol. Acta 19: 323-334.

Hamm, D. \& R. Burton. 2000. Population genetics of black abalone, Haliotis cracherodii, along the central California coast. J. Exp. Mar. Biol. Ecol. 254:235-247.

Henzler, C. M., E. A. Hoaglund \& S. D. Gaines. 2010. FISH-CS: a rapid method for counting and sorting species of marine zooplankton. Mar. Ecol. Prog. Ser. 410:1-11.

Horner, R. A., C. L. Greengrove, K. S. Davies-Vollum, J. E. Gawel, J. R. Postel \& A. M. Cox. 2011. Spatial distribution of benthic cysts of Alexandrium catenella in surface sediments of Puget Sound, Washington, USA. Harmful Algae 11:96-105.

King County. 2010. Initial assessment of nutrient loading to Quartermaster Harbor. Seattle, WA. http://your.kingcounty.gov/dnrp/ library $/ 2010 / \mathrm{kcr} 2119$.pdf.

Kingsford, M., J. Leis, A. Shanks, K. Lindeman, S. Morgan \& J. Pineda. 2002. Sensory environments, larval abilities and local selfrecruitment. Bull. Mar. Sci. 70:309-340.

Le Goff-Vitry, M., A. Chipman \& T. Comtet. 2007. In situ hybridization on whole larvae: a novel method for monitoring bivalve larvae. Mar. Ecol. Prog. Ser. 343:161-172.

Levin, L. 2006. Recent progress in understanding larval dispersal: new directions and digressions. Integr. Comp. Biol. 46:282-297.

Ludwig, W., O. Strunk, R. Westram, L. Richter, H. Meier, Yadhukumar, A. Buchner, T. Lai, S. Steppi, G. Jobb, W. Förster, I. Brettske, S. Gerber, A. W. Ginhart, O. Gross, S. Grumann, S. Hermann, R. Jost, A. König, T. Liss, R. Lüßmann, M. May, B. Nonhoff, B. Reichel, R. Strehlow, A. Stamatakis, N. Stuckmann, A. Vilbig, M. Lenke, T. Ludwig, A. Bode \& K.-H. Schleifer. 2004. ARB: a software environment for sequence data. Nucl. Acids Res. 32:13631371.

Ma, H., J. P. Grassle \& R. J. Chant. 2006. Vertical distribution of bivalve larvae along a cross-shelf transect during summer upwelling and downwelling. Mar. Biol. 149:1123-1138.

McQuaid, C. \& T. Phillips. 2000. Limited wind-driven dispersal of intertidal mussel larvae: in situ evidence from the plankton and the spread of the invasive species Mytilus galloprovincialis in South Africa. Mar. Ecol. Prog. Ser. 201:211-220.

Metaxas, A. 2004. Spatial and temporal patterns in larval supply at hydrothermal vents in the northeast Pacific Ocean. Limnol. Oceanogr. 49:1949-1956.

Miller, P. \& C. Scholin. 2000. On detection of Pseudo-nitzschia (Bacillariophyceae) species using whole cell hybridization: sample fixation and stability. J. Phycol. 36:238-250.

Miller, K., K. Supernault, S. Li \& R. Withler. 2006. Population structure in two marine invertebrate species (Panopea abrupta and Strongylocentrotus franciscanus) targeted for aquaculture and enhancement in British Columbia. J. Shellfish Res. 25:33-42.
National Marine Fisheries Service. 2010. Annual commercial landing statistics. http://www.st.nmfs.noaa.gov/st1/commercial/landings/ annual_landings.html.

Nishitani, L. \& K. Chew. 1984. Recent developments in paralytic shellfish poisoning research. Aquaculture 39:317-329.

North, E. W., Z. Schlag, R. R. Hood, M. Li, L. Zhong, T. Gross \& V. S. Kennedy. 2008. Vertical swimming behavior influences the dispersal of simulated oyster larvae in a coupled particle-tracking and hydrodynamic model of Chesapeake Bay. Mar. Ecol. Prog. Ser. 359:99-115.

Orensanz, J., A. Parma, T. Turk \& J. Valero. 2006. Dynamics, assessment, and management of exploited natural populations. In: S. Shumway \& J. Parsons, editors. Scallops: biology, ecology, and aquaculture, vol. $35,2^{\text {nd }}$ edition. Developments in aquaculture and fisheries science. San Diego, CA: Elsevier. pp. 765-867.

Pacific Coast Shellfish Growers Association. 2009. Shellfish production on the west coast. http://www.pcsga.net/.

Parker, M., P. Jumars \& L. Leclair. 2003. Population genetics of two bivalve species (Protothaca staminea and Macoma balthica) in Puget Sound, Washington. J. Shellfish Res. 22:681-688.

Pineda, J., F. Porri, V. Starczak \& J. Blythe. 2010. Causes of decoupling between larval supply and settlement and consequences for understanding recruitment and population connectivity. J. Exp. Mar. Biol. Ecol. 392:9-21.

Pruesse, E., C. Quast, K. Knittel, B. M. Fuchs, W. Ludwig, J. Peplies \& F. O. Gloeckner. 2007. SILVA: a comprehensive online resource for quality checked and aligned ribosomal RNA sequence data compatible with ARB. Nucl. Acids Res. 35:7188-7196.

Prytherch, H. 1929. Investigation of the physical conditions controlling spawning of oysters and the occurrence, distribution, and setting of oyster larvae in Milford Harbor, Connecticut. Bull. Bur. Fish. 44: 429-503.

Rice, W. R. 1989. Analyzing tables of statistical tests. Evolution 43:223225.

Rocha-Olivares, A., L. E. Calderon-Aguilera, E. Alberto AragonNoriega, N. C. Saavedra-Sotelo \& V. Manuel Moreno-Rivera. 2010. Genetic and morphological variation of northeast Pacific Panopea clams: evolutionary implications. J. Shellfish Res. 29:327335.

Ruiz, G., P. Fofonoff, J. Carlton, M. Wonham \& A. Hines. 2000. Invasion of coastal marine communities in North America: apparent patterns, processes, and biases. Annu. Rev. Ecol. Syst. 31:481-531.

Shanks, A. L. \& L. Brink. 2005. Upwelling, downwelling, and crossshelf transport of bivalve larvae: test of a hypothesis. Mar. Ecol. Prog. Ser. 302:1-12.

Sponaugle, S., R. Cowen, A. Shanks, S. Morgan, J. Leis, J. Pineda, G. Boehlert, M. Kingsford, K. Lindeman, C. Grimes \& J. L. Munro. 2002. Predicting self-recruitment in marine populations: biophysical correlates and mechanisms. Bull. Mar. Sci. 70:341-375.

Straus, K. M., L. M. Crosson \& B. Vadopalas. 2008. Effects of geoduck aquaculture on the environment: a synthesis of current knowledge. Washington Sea Grant technical report no. WSG-TR 08-01. Seattle, WA: Washington Sea Grant. 64 pp.

Todd, C. 2003. Assessment of a trap for measuring larval supply of intertidal barnacles on wave-swept, semi-exposed shores. J. Exp. Mar. Biol. Ecol. 290:247-269.

Turbeville, J., J. Schulz \& R. Raff. 1994. Deuterostome phylogeny and the sister group of the chordates: evidence from molecules and morphology. Mol. Biol. Evol. 11:648-655.

University of Washington. 1976. Quartermaster Harbor: a marine park study of Quartermaster Harbor, Vashon-Maury Island, Washington: a report. Seattle, WA: King County Division of Parks and Recreation. Vol. 1 and Vol. 2 Part 5. 143 pp. and 113 pp.

Vadopalas, B., L. Leclair \& P. Bentzen. 2004. Microsatellite and allozyme analyses reveal few genetic differences among spatially distinct aggregations of geoduck clams (Panopea abrupta, Conrad 1849). J. Shellfish Res. 23:693-706. 
Vadopalas, B., T. W. Pietsch \& C. S. Friedman. 2010. The proper name for the geoduck: resurrection of Panopea generosa Gould, 1850, from the synonymy of Panopea abrupta (Conrad, 1849) (Bivalvia: Myoida: Hiatellidae). Malacologia 52:169-173.

Valero, J., C. Hand, J. Orensanz, A. Parma, D. Armstrong \& R. Hilborn. 2004. Geoduck (Panopea abrupta) recruitment in the Pacific Northwest: long-term changes in relation to climate. Calif. Coop. Ocean. Fish. Invest. Rep 45:80-86.

Washington Department of Fish and Wildlife. 2011. Commercial wild stock geoduck fishery landings and ex-vessel value in Washington. http://wdfw.wa.gov.offcampus.lib.washington.edu/fishing/commercial/ geoduck/geoduck_historic_landings_value_table.pdf.
Widdows, J. 1991. Physiological ecology of mussel larvae. Aquaculture 94:147-163.

Willis, J. 2011. Modeling swimming aquatic animals in hydrodynamic models. Ecol. Model. 222:3869-3887.

Young, C. M. 1995. Behavior and locomotion during the dispersal phase of larval life. In: L. McEdward, editor. Ecology of marine invertebrate larvae. Boca Raton, FL: CRC Press. pp. 249-277.

Yund, P., S. Gaines \& M. Bertness. 1991. Cylindrical tube traps for larval sampling. Limnol. Oceanogr. 36:1167-1177.

Zhang, Z. \& C. Hand. 2006. Recruitment patterns and precautionary exploitation rates for geoduck (Panopea abrupta) populations in British Columbia. J. Shellfish Res. 25:445-453. 